\title{
Can Education Save Money, Energy, and the Climate?- Assessing the Potential Impacts of Climate Change Education on Energy Literacy and Energy Consumption in the Light of the EU Energy Efficiency Directive and the Austrian Energy Efficiency Act
}

\author{
Lars Keller $^{1, *(\mathbb{D}, \text { Maximilian Riede }}{ }^{2}$, Steffen Link $^{3}$, Katharina Hüfner ${ }^{4}$ (D) and Johann Stötter ${ }^{5}$ \\ Institute of Geography, University of Innsbruck, 6020 Innsbruck, Austria \\ 2 Drees \& Sommer, 70569 Stuttgart, Germany; maximilian.riede@dreso.com \\ 3 Fujitsu, 74172 Neckarsulm, Germany; steffen.link@tds.fujitsu.com \\ 4 Department of Psychiatry, Psychotherapy, Psychosomatics and Medical Psychology, Division of Psychiatry II, \\ Medical University of Innsbruck, 6020 Innsbruck, Austria; katharina.huefner@tirol-kliniken.at \\ 5 Climate Change Center Austria, 1190 Vienna, Austria; johann.stoetter@uibk.ac.at \\ * Correspondence: lars.keller@uibk.ac.at
}

check for updates

Citation: Keller, L.; Riede, M.; Link, S.; Hüfner, K.; Stötter, J. Can Education Save Money, Energy, and the Climate? - Assessing the Potential Impacts of Climate Change Education on Energy Literacy and Energy Consumption in the Light of the EU Energy Efficiency Directive and the Austrian Energy Efficiency Act. Energies 2022, 15, 1118.

https://doi.org/10.3390/en15031118 Academic Editors: Sergio Ulgiati, Marco Casazza and Pedro L. Lomas

Received: 21 December 2021

Accepted: 28 January 2022

Published: 2 February 2022

Publisher's Note: MDPI stays neutral with regard to jurisdictional claims in published maps and institutional affiliations.

Copyright: (C) 2022 by the authors. Licensee MDPI, Basel, Switzerland. This article is an open access article distributed under the terms and conditions of the Creative Commons Attribution (CC BY) license (https:// creativecommons.org/licenses/by/ $4.0 /)$.

\begin{abstract}
The Austrian Education Energy Initiative ETSIT has been established as a response to the EU Energy Efficiency Directive and the Austrian Energy Efficiency Act. This paper investigates the energy literacy of its young participants, i.e., 6000 primary and secondary school students altogether, on a cognitive, affective and behavioural level, and it compares the putative energy-saving effectiveness of the workshops to that of conventional energy audits.For the current analysis, data from, 640 students who validly answered an online survey shortly after participating in one of the energy education workshops, and 353 students who validly answered the online survey approximately one year after having participated (overall $n=993$ ) were analysed. The results indicate that ETSIT raises students' energy literacy on a cognitive, affective and behavioural level with about three-quarters of participants claiming they will positively change their energy consumption behaviour in the future as a result of workshop participation. This is true shortly after participation in the workshops, and also at the 1-year follow-up. In its second impact perspective, this paper delivers an innovative attempt to look at education from a cost-benefit analysis. A default formula for energy audits is adopted to quantify the kilowatt hours (and thus emissions and costs) saved through workshop participation. Despite limitations, the surprising results show that such workshops can compete with conventional energy audits, and that education can, in fact, help save money, resources, and, most important of all, the climate.
\end{abstract}

Keywords: energy education; climate education; education for sustainable development; energy literacy; energy consumption; impact assessment; EU Energy Efficiency Directive; Austrian Energy Efficiency Act

\section{Introduction}

The depletion of non-renewable natural resources coupled with advancing climate change caused by anthropogenic emissions of greenhouse gases needs to be tackled urgently, effectively, and in a coordinated manner both globally and at a local level. Education can and must play an important role in corresponding strategies and efforts.

Summarizing shortly, the world has been informed about the "Limits of Growth" by the Club of Rome in the 1970s [1]; the 21 Agenda 1990 [2] has coined the idea of "Sustainable Development", and, since then until the present day, many alarming reports have been published by the Intergovernmental Panel on Climate Change (IPCC), with the latest series 
just out in 2021 [3]. Since 1995, the Conference of the Parties (COP) as the supreme body of the United Nations Framework Convention on Climate Change, with the latest COP26 meeting in Glasgow in 2021, has strengthened the international response to climate change (and, increasingly, also the continuous loss of biodiversity), and highlighted the need for collective action [4]. Yet it is only since the fifth series of IPCC reports [5], the Paris Agreement [6], and particularly the introduction of the Sustainable Development Goals (SDGs) [7], and the latest reports on Education for Sustainable Development [8-10] that the strong interrelation between Sustainable Development (SD) and Education for Sustainable Development (ESD), and thus the importance of SDG4 and ESD for reaching all SDGs [11], have been universally acknowledged in important international agreements [12].

As for climate and energy policy, the European Commission presented a legal package in 2008, which was commonly known as the '20-20-20 goals' [13]. It addressed climate change by focusing on a restrictive climate and energy policy, and aspired that, by 2020, the EU should have cut greenhouse gas emissions by $20 \%$, increased the share of energy from renewable sources by $20 \%$ as well as increase energy efficiency by $20 \%$ in comparison with 1990 levels. The Energy Efficiency Directive by the European Union in 2012 was adopted in response to the fact that EU Member States were not on track to reduce primary energy consumption by $20 \%$ by 2020 and necessitated a change in consumer behaviour and energy consumption practices [14-16]. Among other important changes, education was put high on the agenda. This is even more evident in the latest strategies and efforts by the EU in the so-called European Green Deal, adopted in 2019. The wording of the proposal context says it all as "the Commission set out a new growth strategy that aims to transform the EU into a fair and prosperous society, with a modern, resource-efficient and competitive economy where there are no net emissions of greenhouse gases in 2050 and where economic growth is decoupled from resource use. It also aims to protect, conserve and enhance the EU's natural capital, and protect the health and well-being of citizens from environment-related risks and impacts. To reach these objectives, energy efficiency must be prioritised" [17]. As a consequence, the European Commission has also issued a new proposal (not yet agreed upon) for yet another directive on energy efficiency in 2021, increasing the efforts of "reducing greenhouse gas emissions to at least $55 \%$ below 1990 levels by 2030" [18]. Within this document, it becomes clear that "energy efficiency is (still) a key area of action, without which the full decarbonisation of the Union's economy cannot be achieved" (Article 6), that "the provision of education, training and specific information (... ) on energy efficiency" still plays an explicit role (Article 5), and that "Member States should take into account the fact that the successful implementation of new technologies for measuring energy consumption requires enhanced investment in education and skills for both users and energy suppliers" (Article 77). Consequently, it has been valued in the past years that energy education could be key in bringing about changes in consumer behaviour and energy consumption practices in rather a bottom-up approach.

As a direct consequence of the EU Energy Policy from 2006 onwards, EU countries were required to transpose the binding measures into their national laws. Austria passed an Energy Efficiency Act, which turned legally binding in 2015. The Austrian Energy Efficiency Act aims to bring about a cost-optimized, secure and sustainable energy supply by increasing energy efficiency and the share of renewable energy in the energy mix, as well as reducing greenhouse gases [19]. According to Austrian law, energy suppliers have to execute energy efficiency measures directed at their clients' consumption. The measures have to annually reduce emissions by the amount of $0.6 \%$ on their previous year's consumption level. In order to be legally accepted and 'offsettable' as an effective energy efficiency measure, energy suppliers have to prove that the measure results in verifiable and measurable or, at least, estimable energy efficiency improvement or primary energy savings [14]. While the impact of energy efficiency measures in sectors like housing (e.g., thermal insulation), transport (e.g., electro mobility) or industry (e.g., retrieval of industrial waste heat) is relatively easily quantifiable, there is not yet an equivalent understanding of the impact of cross-sectorial measures like information and awareness-campaigns, or 
training and energy conservation programmes on the actual energy consumption. In Austria, most energy suppliers (directly or indirectly) make considerable investments in energy information and education initiatives.

Despite these hands-on efforts, not enough research has been done in the evaluation and impact assessment of such activities. This is particularly true for studies examining the actual energy savings in kilowatt hours or avoided carbon dioxide emissions triggered by educational programmes [20-22]. Sharygin [23] calculated the carbon effects of an educated future and reached the conclusion that each year of education could be associated with an average reduction in $\mathrm{CO}_{2}$-equivalent emissions of $-466 \mathrm{~kg}$ /year, thus concluding that education can translate into fewer emissions per household. Apart from these (rather general) analyses, and despite objections by critics of cost-benefit analyses involving environmental parameters [24], several energy efficiency programmes in the housing sector have been examined through a cost-benefit-analysis lens, e.g., [25-30]. More holistic projects and evaluations did not only look at energy saving on the financial benefit side but expanded it to environmental benefits and health and comfort improvements [31,32], or they emphasised the positive effects on energy literacy, and, at the same time, the quality of life of the participants and their communities [33].

Despite all efforts, however, DeWaters et al. [34] compiled an extensive review in which they state that there is neither an equivalent understanding in the field of assessing the effectiveness of energy literacy education nor a holistic tool to measure all attributes-a view still regarded as valid today (e.g., in the 2nd Handbook of Climate Communication [35]). In contrast to the environmental literacy domain, evaluation tools for energy literacy are either outdated [36-41], limited on cognitive outcomes [42-44], or measure content-based knowledge only [45-47]. The few existing holistic evaluation tools are, due to their length and complex wording, mostly inappropriate for students. Responding to this research gap, with "The Energy Literacy Questionnaire", DeWaters et al. [34] developed an extensive evaluation tool, which contains of 17 affective, 10 behavioural and 30 cognitive items. Thus, a systematic procedure was introduced to create a valid, reliable measure of energy literacy (however limited to the use with English-speaking students in the United States).

Undoubtedly, content knowledge, awareness and self-efficacy are regarded to be important domains of energy-literacy, yet, only actual behavioural changes have an impact on the climate. Therefore, legal frameworks, such as the Austrian Energy Efficiency Act, have a high interest in the measurement of the actual impact of behavioural change on the energy consumption triggered by a particular measure, e.g., by an information campaign or an educational initiative [19].

There are acknowledged standards for the estimation of the impact of energy audits conducted by an energy consultant at a private household on the actual energy consumption of the private household in Austria [48] as well as meta-studies about the impact of different energy audit formats on cognitive, affective and behavioural aspects [49]. However, an equivalent for energy education programmes does not yet exist. The study at hand addresses this research gap by outlining basic information regarding the Austrian Energy Education Initiative 'Die Energiewende-Schulinitiative Tirol' (Engl. Energy TransitionSchool Initiative Tyrol, short ETSIT) [50], and by presenting the methodology used to evaluate this initiative at cognitive, affective and intentional level.

Secondly, due to a lack of existing methodology in this pioneering field, the authors apply a monitoring default formula borrowed from energy advisory evaluation in order to demonstrate a cost-benefit analysis of ETSIT. In order to successfully convince policy makers and state officials that educational interventions paid by energy suppliers should be legally accepted and 'offsettable' as an effective energy efficiency measure in Austria, we decided to apply a robust and widely applied model used in Austrian energy auditing (see Section 3.2). This model was developed by the official Austrian Energy Agency by order and on account of the former Austrian Ministry of the Economy and Families BMWFJ (now the Austrian Ministry of Digital and Economic Affairs). The methods published in a 120-page document by the Austrian Energy Agency [48] are all directed at complying with EU legislation and 
the consequent Austrian Energy Efficiency Act. In a bottom up-approach, the main types of energy saving potentials are presented, e.g., for buildings, illumination, energy audits for businesses and private households, and various technological possibilities, always in connection with the question of how to measure and calculate the savings in compliance with legal requirements and specifications. It is the most comprising and professional attempt to describe this connection in detail and for the Austrian situation within the time of the study period (and beyond), and the models and formulas presented are widely applied in Austria. The default formula used in our study originates from this publication, and thus delivers a solid base (politically, but also scientifically) for our argumentation.

As a result, the authors present assumptions about a spectrum of potentially conserved kilowatt hours through the education workshops, identify and discuss perils and pitfalls of such an evaluation methodology, and draw further conclusions on what can be learnt from both a cost-benefit and educational perspective.

\section{Methods}

\subsection{Energy Education Initiative "Energy Transition-School Initiative Tyrol" (ETSIT)}

The Energy Education Initiative ETSIT contains eight 90 min energy education workshop formats which all cover the aspects: (i) climate change and energy nexus at the local level, (ii) private household energy consumption, (iii) energy-saving measures for individuals, and (iv) renewable energy sources (for more information see [50]). The group of workshop instructors, all employed by "Energie Tirol" [50], an independent, but statefinanced energy office, consists of energy technicians, educators, architects, and energy auditors who are trained both thematically and pedagogically prior to the workshops. Financed by local energy supply companies, teachers can book the workshops for free. The authors of this study have contributed both to the development of workshops and evaluations from a scientific perspective.

In the period between December 2012 and October 2018, more than 6000 primary and secondary school students participated in around 300 workshops provided by the Energy Education Initiative in 175 schools [50]. Since 2019/2020, the initiative has been put on hold due to COVID-19. All results presented in this study are from the years before COVID-19 and have thus been completely unimpacted by any influences of the pandemic, an important asset during these difficult (research) times [51].

Psychological models show that old habits are a very strong barrier to implement pro-environmental behaviour [52]. Therefore, it is important to prevent the development of such habits as soon as possible by turning pro-environmental behaviour into young people's 'default setting'. From a psychological point of view, all redesigned workshops follow an antecedent strategy, which, in contrast to consequence strategies (e.g., feedback, rewards), aims to influence cognitive, affective and behavioural determinants prior to the performance of environmentally significant behaviours [49].

From an educational perspective, the theoretical and practical approach of all redesigned workshops is firmly based on the assumptions of moderate constructivism [53-57], conceptual change [58-64], and inquiry-based-learning [65-72]. They all consist of handson activities making use of and activating the students' prior knowledge and experiences, ensuring a high level of engagement, and aiming at the same target-i.e., raising students energy literacy at cognitive, affective and behavioural level.

\subsection{Assessing Energy Literacy in Online-Surveys}

The evaluation of the workshops (ETSIT) is understood in the sense of Döring and Bortz [73] as the systematic application of empirical research methods for the impact assessment of a social intervention. The instruments used to measure the impact of the participation among the students are online-based questionnaires. Kuckartz and Rädiker [74] compiled an overview of advantages and disadvantages of using online-based questionnaires for data collection in educational contexts. One of their main conclusions was that the many advantages outweigh the few disadvantages, and therefore they recommend it, if 
used according to the DeGEval-standards [75] as a valuable contribution to an adequate observation of the object of investigation.

The data evaluated in this analysis were collected via completely anonymous online surveys. Separate versions, which differ only slightly in length and complexity of the wording, were applied as part of this research to account for differences between the cognitive abilities of the primary school and secondary school students. The online-based questionnaire used in the study and survey one was applied directly after the workshop (S1 in Table 1). It was designed to be a combination of closed and open questions with a total duration of no more than $15 \mathrm{~min}$ per student to ensure an increased response rate and to prevent denial $[74,76]$. The teachers of the participating classes were requested to coordinate their students completing the online-survey two days after the workshop at the latest (participation of the classes was at the teachers' discretion). A second study and survey evaluated the long-term effects of the educational workshops using a subset of questions from the first study survey (S2 in Table 1). It was carried out at a time distance of roughly one year after the students' participation in a workshop. The duration here was designed to take no more than five minutes in order to keep the feedback numbers as high as possible. Given the facts of the time-distance, and that teachers and students had changed classes or left school, and various other difficulties, the response rate in the second study survey was not as high as in the first one.

Table 1. Students' self-reporting about the potential future impacts of participating in an ETSIT workshop (rounded percentage) directly after (up to two days after) and approximately one year after the workshop.

\begin{tabular}{|c|c|c|c|c|c|c|c|c|c|}
\hline & \multicolumn{2}{|c|}{ Fully Disagree } & \multicolumn{2}{|c|}{ Rather Disagree } & \multicolumn{2}{|c|}{ Rather Agree } & \multicolumn{2}{|c|}{ Fully Agree } & \multirow[t]{2}{*}{$p$ Value } \\
\hline & $\mathrm{S1}^{+}$ & $\mathrm{S}^{++}$ & S1 & S2 & S1 & S2 & S1 & S2 & \\
\hline \multicolumn{10}{|l|}{ COGNITIVE ATTRIBUTES: } \\
\hline \multicolumn{10}{|c|}{ Through participating in the workshop ... } \\
\hline ... my knowledge about energy has increased. & $10 \%$ & $10 \%$ & $16 \%$ & $12 \%$ & $35 \%$ & $38 \%$ & $39 \%$ & $41 \%$ & 0.287 \\
\hline ... I have learnt how to conserve energy. & $8 \%$ a & $5 \%{ }^{a}$ & $13 \%{ }^{a}$ & $8 \% \mathrm{~b}$ & $30 \%{ }^{a}$ & $30 \%{ }^{a}$ & $51 \%^{a}$ & $57 \%$ a & 0.047 \\
\hline $\begin{array}{l}\text {... I have learnt how to contribute to mitigate } \\
\text { climate change. }\end{array}$ & $10 \%$ & $9 \%$ & $16 \%$ & $15 \%$ & $35 \%$ & $32 \%$ & $39 \%$ & $44 \%$ & 0.545 \\
\hline $\begin{array}{l}\text {... I have become aware of my personal } \\
\text { behaviour's impacts on climate change. }\end{array}$ & $10 \%{ }^{a}$ & $8 \%{ }^{a}$ & $18 \%{ }^{a}$ & $12 \%$ & $33 \%{ }^{a}$ & $39 \%$ b & $40 \%{ }^{a}$ & $41 \%{ }^{a}$ & 0.040 \\
\hline \multicolumn{10}{|l|}{ AFFECTIVE ATTRIBUTES: } \\
\hline \multicolumn{10}{|c|}{ Through participating in the workshop ... } \\
\hline $\begin{array}{c}\text {... my interest in energy and energy conservation } \\
\text { has increased. }\end{array}$ & $9 \%$ & $11 \%$ & $18 \%$ & $18 \%$ & $36 \%$ & $32 \%$ & $37 \%$ & $39 \%$ & 0.501 \\
\hline ... my interest in climate change has increased. & $14 \%$ & $11 \%$ & $19 \%$ & $16 \%$ & $32 \%$ & $34 \%$ & $36 \%$ & $38 \%$ & 0.478 \\
\hline $\begin{array}{l}\text {... I have become aware of the importance of } \\
\text { energy for my personal future. }\end{array}$ & $7 \%$ a & $8 \%{ }^{a}$ & $14 \%{ }^{a}$ & $7 \%$ b & $32 \%{ }^{a}$ & $31 \%{ }^{a}$ & $48 \%{ }^{a}$ & $54 \%$ a & 0.016 \\
\hline $\begin{array}{l}\text {... I have become aware of the importance of } \\
\text { energy for the future of mankind. * }\end{array}$ & $6 \%$ & $6 \%$ & $10 \%$ & $9 \%$ & $34 \%$ & $28 \%$ & $50 \%$ & $58 \%$ & 0.246 \\
\hline \multicolumn{10}{|l|}{ BEHAVIORAL ATTRIBUTES: } \\
\hline \multicolumn{10}{|c|}{ Through participating in the workshop ... } \\
\hline ... I will make wise use of energy in the future. ${ }^{* *}$ & $6 \%{ }^{a}$ & $8 \%^{a}$ & $16 \%{ }^{a}$ & $9 \% \mathrm{~b}$ & $38 \%^{\mathrm{a}}$ & $31 \%^{\mathrm{a}}$ & $41 \%^{\mathrm{a}}$ & $52 \%^{b}$ & 0.012 \\
\hline ... I will try to save energy in my day-to-day life. & $11 \%^{\mathrm{a}}$ & $11 \%^{a}$ & $16 \%^{a}$ & $6 \% \mathrm{~b}$ & $31 \%^{a}$ & $36 \%^{a}$ & $42 \%^{\mathrm{a}}$ & $47 \%^{\mathrm{a}}$ & 0.001 \\
\hline
\end{tabular}

N.B.: S1 ${ }^{+}$: Survey 1 , directly after (up to two days after) the workshop, $n=640$; S2 ${ }^{++}$: Survey 2, approximately one year after the workshop $n=353$; Overall $n=993$; * 240 missings; ${ }^{* *} 429$ missings; Differences between S1 and S2 were calculated using chi-square test (significance was set to $p<0.05)$. Superscript letters $\left({ }^{\mathrm{a}}, \mathrm{b}\right.$ in shaded lines) indicate column proportions for respective answer that differ significantly between S1 and S2 using z test ( $p<0.05$ corrected for multiple comparisons by Bonferroni method).

After a few general items at the beginning, both online surveys (provided on the platform soscisurvey.de) contained matrices in which the students were asked to self-report the impact of their participation in the workshop on a four-level ordinal Likert scale ranging from 'fully agree' to 'fully disagree' $[77,78]$. The selection of items (for more information cf. [79]) was based on the cognitive, affective and behavioural attributes of energy literacy, inspired by 'The Energy Literacy Questionnaire' developed by DeWaters et al. [34], but 
adapted according to the participants' language and needs. Skipping questions was possible and thus resulted in missing answers.

\subsection{Sample and Statistical Analysis}

Overall, this analysis combines data from two studies, one on evaluating the immediate effects of (max. two days after) the workshops ( $n=640,43 \%$ female, $57 \%$ male), and a second study on the longer term effects, i.e., a follow-up after roughly one year after workshop participation ( $n=353,53 \%$ female, $47 \%$ male), adding up to an overall $n$ of 993 students from Austrian primary and secondary schools.

Statistical analyses are performed in EXCEL ${ }^{\circledR}$ and SPSS $^{\circledR}$. Distributions of students' answers between the two time points (S1 directly (max. up to two days) after the workshop, and $\mathrm{S} 2$ = follow-up, approximately 1 year after participation in the workshop) are analysed using Chi-square test and z-test to compare column proportions for respective answers. $p<0.05$ is considered significant in all analyses. For $z$-tests, corrections for multiple comparisons were applied using Bonferroni Method.

\subsection{Cost-Benefit Analysis with Default-Formula}

The cost-benefit analysis is based on the central findings of the online surveys, which showed how many students reported they would intend to positively change their future behaviour as a consequence of having participated in the workshop. While measuring the financial costs of the workshops is relatively simple, quantifying the benefits of ETSIT in terms of kilowatt hours is a challenging task underpinned with many uncertainties (cf. Section 4.3).

In this study, a default formula commonly used to quantify the impact of energy audits between energy experts and private households in Austria (cf. Section 1) is adopted to attempt to quantify the spectrum of energy being saved through the workshops. In general, it is distinguished between three quality levels of energy audits (eQ1-eQ3) according to their duration, intensity and individuality. An eQ1 audit contains a personified (internet-based) consumption analysis with a duration of at least $15 \mathrm{~min}$. If this audit is undertaken face-toface and lasts at least thirty minutes, it classifies as eQ2 audit. An eQ3 audit contains an on-site assessment, an individual energy concept comprising the entire energy consumption as well as potential saving options at household level, lasts at least $60 \mathrm{~min}$ and has to be done by independent energy advisers. The energy saving factor depends highly on the quality level of the energy audit. While an eQ1 audit accounts for an energy saving factor of only $0.25 \%$ of the average household's annual energy consumption (31,700 kWh [80]), an eQ2 audit amounts to 1\%, an eQ3 audit even to $3 \%$ of the annual household energy consumption [48].

In contrast to the well-acknowledged quality level descriptions in the energy audit domain, there is no quantitative equivalent for energy education programmes, and the methodology of this study does not lead to absolute data either. However, efforts are made to approximately define the quality level of a workshop by comparing its characteristics to those of an energy audit. Although young people's scope of action is hard to grasp, there are many arguments for their strong influence on friends and family members, and their increasing possibilities to contribute to energy consumption/reduction [81]. Beyond that, the energy education workshop with its duration of 90 min exceeds conventional energy audits regarding the factor time (although a $90 \mathrm{~min}$ programme is considered as rather short in educational contexts).

Referring to the characteristics of the three quality levels, the authors assume that the energy saving factor of the energy education workshops described above could lie in between $\mathrm{eQ1}$ and eQ3. Therefore, in the following calculation with the default formula, the authors use an eQ1, eQ2 and also an eQ3 level audit as a baseline to generate a range of potential impacts. 


\section{Results}

\subsection{Results of Self-Reporting Online Surveys about Energy Literacy Attributes}

The results of S1 and S2 self-reporting (see Table 1) show that the workshops lead to an increase in the participating students' energy literacy.

Looking at the cognitive attributes of energy literacy induced by workshop participation in the first survey (S1, directly after the workshop), 74\% (39\% fully, 35\% rather) agree that their knowledge about energy increased and 81\% (51\% fully, 30\% rather) agree that they have also learnt how to save energy. The follow-up survey (S2, roughly one year after workshop participation) confirms these strong results: Knowledge increase from workshop participation is still substantiated by $79 \%$ (41\% fully, 38\% rather), $87 \%$ (57\% fully, 30\% rather) confirming that they have learnt how to save energy.

Strikingly, the group of students stating that they rather disagree that they have learnt how to save energy through the workshop has fallen significantly between S1 and S2, and so the group of students stating that they rather or fully agree they have learnt how to save energy grows by $6 \%$. Even more striking is the positive outcome as to students' awareness of their own behaviours' impacts on climate change with $73 \%$ (40\% fully, 33\% rather) agreeing on the increase triggered by the workshops in S1. S2 with $80 \%$ (41\% fully, $39 \%$ rather), again, shows a significant positive increase one year later.

Overall, the results demonstrate that ETSIT workshops have the potential to trigger a considerable increase in students' fundamental cognitive base needed to become more energy literate.

Examining the affective level feedback resulting from workshop participation opens another avenue for consideration and deeper insights. In S1, 73\% (37\% fully, 36\% rather) agree that their interest in energy and energy conservation has increased (roughly the same numbers for the item interest in climate change), while $80 \%$ (48\% fully, $32 \%$ rather) agree that they have become aware of the importance of energy for their personal future (similar percentages for the item awareness of the importance of energy for the future of mankind). In $\mathrm{S} 2$, the numbers speak a similar language with 71\% (39\% fully, 32\% rather) and 85\% (54\% fully, 31\% rather) agreeing. As to the latter item awareness of the importance of energy for their personal future, there is a significant decrease in those rather disagreeing, and thus a striking increase in the group of agreeing students, which is yet another very positive outcome for the ETSIT energy education programme.

This positive view is also, and even more strikingly, confirmed by a look at the behavioural attributes in Table 1 . S1 results show that $79 \%$ (41\% fully, 38\% rather) of the students agree on the statement that, through participating in the workshop, they will make wise use of energy in the future. The same is true in S2 with even $83 \%$ (52\% fully, 31\% rather) agreeing. Likewise, 73\% (42\% fully, 31\% rather) in S1, and, notably, 83\% in S2 (47\% fully, 36\% rather) agree that from now on they will try to save energy in their day-to-day life. The latter item shows a significant decrease in those rather disagreeing (and thus quite an increase in the group agreeing) between S1 and S2, the first a significant increase in those fully agreeing.

Acknowledging that, at the end of the day, it is behavioural (and not cognitive and affective) attributes and changes which are needed for energy-efficient and climate-friendly action in everyday life, the results of ETSIT impact on energy literacy are promising. Combining the two behavioural attributes of energy literacy in particular, it can be concluded that roughly three-quarters of the participants claim they will change their future behaviour in a pro-environmental manner. This central result is used for the simulation of a cost-benefit analysis in the next step.

\subsection{Results of Cost-Benefit Analysis with Default Formula}

Without taking the limitations of this study into consideration at this point (cf. Section 4.3), and based on the findings presented above, we assume that approximately $75 \%$ of the total 6000 participating students, i.e., 4500 students, may be regarded as the number of young 
consumers who will make wise use of energy in the future, and try to save energy in their day-to-day lives.

Since there is no equivalent for the impact assessment and quantification of energy education programmes, the following energy audit default formula (see Table 2 for explanations) is used to constitute the amount of energy saved through the energy education workshops:

$$
\text { EStot }=(\mathrm{nQn}-\mathrm{fr} 1) \times \mathrm{EECHH} \times \mathrm{eQn} \times \mathrm{rb} \times \mathrm{so} \times \mathrm{cz}
$$

Table 2. Overview of default-formula elements.

\begin{tabular}{cr}
\hline Abbreviation & Description \\
\hline EStot & total energy savings (kilowatt hours per annum) \\
\hline $\mathrm{nQn}$ & number of energy audits per quality level $\mathrm{n}$ \\
\hline $\mathrm{Frn}$ & number of energy audits per quality level $\mathrm{n}$, which would have taken place \\
without measure (free rider) $(=0)$
\end{tabular}

The quality level of the respective energy audit plays an important role in the default formula. As previously discussed, the ETSIT workshops cannot be clearly labelled according to the quality level categories of energy audits (cf. Section 2.4). However, comparing the characteristics of the audit and the educational workshops, it can be assumed that the quality level of the workshops lies in between an eQ1 and eQ3 audit (see details in Section 2.4). By calculating minimum, medium, and maximum energy savings (just like in Austrian household energy audits), we thus do not conclude by giving a fixed amount of energy saved (in kWh) or fixed costs for saving $1 \mathrm{kWh}$ in our energy education workshops, but always present a range of energy savings or costs in the following calculations.

Assuming that the workshops have the same impact as an eQ1 energy audit, they account for the conservation of:

(1) EStot $_{\min }=(4500-\mathrm{fr} 1) \times 31,700 \mathrm{kWh} \times 0.0025 \times 1 \times 1 \times 1$

(2) EStot $_{\min }=(4500-0) \times 31,700 \mathrm{kWh} \times 0.0025 \times 1 \times 1 \times 1$

(3) EStot $_{\min }=356,625 \mathrm{kWh}$

Assuming the workshops are equal to the quality level of an eQ2 audit, they account for the conservation of:

(1) $\quad$ EStot $_{\text {med }}=(4500-\mathrm{fr} 1) \times 31,700 \mathrm{kWh} \times 0.01 \times 1 \times 1 \times 1$

(2) EStot $_{\text {med }}=(4500-0) \times 31,700 \mathrm{kWh} \times 0.01 \times 1 \times 1 \times 1$

(3) EStot $_{\text {med }}=1,426,500 \mathrm{kWh}$

Using an eQ3 energy audit as the benchmark, it can be assumed that the amount of energy conserved through the workshop initiative accounts for:

(1) EStot $_{\max }=(4500-\mathrm{fr} 1) \times 31,700 \mathrm{kWh} \times 0.03 \times 1 \times 1 \times 1$

(2) EStot $_{\text {max }}=(4500-0) \times 31,700 \mathrm{kWh} \times 0.03 \times 1 \times 1 \times 1$

(3) EStot $_{\max }=4,279,500 \mathrm{kWh}$

Hence, the spectrum of the actual energy conservation through the entire Energy Education Initiative ETSIT (300 workshops) ranges approximately from 0.36 GWh over $1.43 \mathrm{GWh}$ to $4.28 \mathrm{GWh}$. The amount of energy saved through one of the 300 workshops thus lies in the range of ca. $1189 \mathrm{kWh}$ and 14,265 kWh.

While the energy-saving (and thus the financial) benefits of the initiative can so far only be vaguely estimated with the calculation presented above, the financial costs are easy 
to add up. The average total costs per workshop are given at EUR 350, including the costs for instructors and administration, which adds to EUR 105,000 for 300 workshops. Since the development of the workshops concepts and evaluation was third party funded, these costs have not been considered in this analysis.

Comparing the financial costs of the workshops on the one hand with the amount of energy saved on the other, it is possible to define a spectrum which demonstrates the costs of saving $1 \mathrm{kWh}$.

Maximum costs for conserving $1 \mathbf{k W h}=$ total costs of initiative $/$ EStot $_{\min }$

$=$ EUR 105,000/356,625 kWh = ca. 0.29 EUR/kWh

Medium costs for conserving $1 \mathbf{k W h}=$ total costs of initiative/EStot ${ }_{\text {med }}$

$=$ EUR 105,000/1,426,500 kWh = ca. 0.07 EUR/kWh

Minimum costs for conserving $1 \mathbf{k W h}=$ total costs of initiative $/$ EStot $_{\max }$

$=$ EUR 105,000/4,279,500 kWh = ca. 0.02 EUR/kWh

Summing up: The costs for saving $\mathbf{1} \mathbf{k W h}$ with the Energy Education Initiative ETSIT range from EUR 0.02 to EUR 0.29.

\section{Discussion}

\subsection{Discussion of Results of Self-Reporting Online Surveys about Energy Literacy Attributes}

The results of both surveys (see Table 1) show that the workshops lead to an (even longer lasting) increase in the participating students' energy literacy and change of behaviour. However, the relationship between cognitive, affective and behavioural aspects remains a controversy. Although early models of environmental behaviour claim a linear correlation between knowledge, attitude and behaviour [82], many recent studies disagree with these findings, e.g., [52]. Instead, the relationship can be characterised as very complex, not at all mono-directional, and certainly influenced by many additional factors, such as feedback, social norms, economic situation, values, and beliefs [83-89]. However, there are several studies which provide evidence that support the relationship between cognitive knowledge of and affective attitudes toward environmental issues [90-94].

Although there are many controversies about the correlation between the attributes, many authors (e.g., [95]) found that the correlations between affective and behavioural subscales are significantly higher than those between cognitive and affective as well as cognitive and behavioural [52]. Therefore, high achievements in the affective attributes increase the probability that the students will change their behaviour, and it indicates that they might possess a general understanding and acceptance for measures tackling climate change (e.g., legal regulations).

Children and teenagers' actual use of energy and their potential to reduce it has not been examined comprehensively enough to determine whether a change in their behaviour has a similar environmental impact to that of an adult. However, homes with children, and particularly with teens, have been evidenced to be high energy consuming households (e.g., for the UK [96]), and from studies on children's and teenagers' environmental attitude and behaviour we know that until they are 14 years of age, both increase, and then (esp. without further educational support) decline until they are 18 [97]. Besides the use of electronic devices, which accounts for only a small amount of an average Austrian household's energy consumption, children and teens are also likely to have influence over lighting use, heating, hot water use, mobility behaviour and general consumption.

It also remains unclear whether or not the Energy Education Initiative ETSIT also affects the behaviour of the participants' families and friends [81]. Indeed, taking into account the energy-saving factors of free-rider effects [98], rebound effects [99,100] or spillover effects [101-104], the carbon savings could be significantly higher. 


\subsection{Discussion of Results of Cost-Benefit Analysis with Default Formula}

The results of this study should not be seen as the solution, but rather as a starting point for any further approximations in this matter. Let us not forget: The annual costs of climate change consequences in Austria at this time and age are estimated at about 15-20 billion Euro, tendency ever increasing [105], which would be reason enough to step up efforts for climate mitigation at almost any cost. However, it also makes a lot of sense to look at soft measures like information, awareness or education campaigns from a cost-benefit analysis perspective.

This study contributes to the discussion of measuring allegedly unmeasurable parameters. Without underestimating the uncertainties in the impact assessment, it can be stated that energy education initiatives such as ETSIT can have a considerable impact on reducing the actual energy consumption of individuals and private households. Although the range of energy potentially saved through one workshop is wide, the impact on the energy consumption could be as high (or possibly higher) as that from a conventional energy audit. In a current spillover-approach, Arimura et al. [104] (p. 761) look at "seemingly unrelated interventions", i.e., the impact of environmental education at firms on the electricity consumption at the employees' houses. By measuring the education intervention effects with the help of an environmental management system, they can prove that those who face ISO14001 at workplace actually also save electricity at home. This finding strongly reinforces the approach taken in the present manuscript.

The results presented above show that a workshop which costs EUR 350 might amount to an energy saving of between ca. $1189 \mathrm{kWh}$ and 14,265 kWh, and the expenditures can thus be summarized as being invested wisely also from a cost-benefit perspective. The actual costs of a conventional energy audit in Austria differ depending on quality level but exceed EUR 350. Based on this analysis, one could assume that energy education workshops could compete with conventional energy audits, although costs and benefits of behavioural intervention programmes are not very well studied in general. Allcott and Mullainathan [106] found that the cost-effectiveness of energy audits with behavioural interventions range from .016 USD $/ \mathrm{kWh}$ to $.064 \mathrm{USD} / \mathrm{kWh}$. However, a precise costbenefit comparison of energy audits and energy education programmes clearly requires further research.

A further point of critical reflection could also consider that, in the energy audit domain, it is assumed that the impact of an energy audit lasts for approximately two years [48]. As the survey results show a fairly lasting effect on the participants through the ETSIT workshops (although very time-restricted and only a one-time exposure), it could be assumed that the impact might last equally long. Yet this clearly has to be investigated further in future studies.

\subsection{Discussion of Limitations}

There are limitations and uncertainties involved at different stages of the study. The following explains how the authors have dealt with and attempted to reduce them.

\subsubsection{Survey Instrument Validity}

In order to ensure survey instrument validity and reliability whilst endeavouring to prevent measurement errors, a variety of measures have been undertaken in the development process of the questionnaire [107]. First of all, the survey was co-developed together with different primary and secondary school teachers, and also with the workshop instructors for pedagogic and content appropriateness. Before it was applied to the sample, the questionnaire had been pre-tested with a group of students in non-participating schools. Before the actual participants filled in the survey, they were informed of the importance of responding honestly rather than giving answers that might be deemed desirable by the workshop instructors as well as their teachers. In order to minimize experimenter expectancy effect, the authors of the study prevented any interpersonal contact with the study participants [108]. Alongside the standardised online survey for the students, the teachers 
were provided with a feedback form with open questions about their general impressions of the workshop. This complementary qualitative survey instrument was applied to compare the results of teachers and students, and to examine whether the teachers' general feedback was in line with those of the students. This procedure follows a mixed-methods approach [109] focusing on the mutual verification of empirical insights. We have not included further information on the teacher survey in this study as the semi-standardised feedback has never been intended to qualify for further detailed analysis. However, these surveys draw a generally positive and affirmative picture about the workshops and their impacts on the students, and thus further confirm our results from the students' surveys S1 and S2.

\subsubsection{Knowledge-Action Gap and Self-Reporting}

In this study, one major uncertainty requiring discussion is the phenomenon that there can be a considerable knowledge-action-gap, i.e., between knowing about the possibilities of efficient energy use and applying it in the real world [110-115]. So, unfortunately, there is a possibility that self-reported behaviours (as requested in the surveys) might not correspond with the study participants" real action. This conflict is discussed intensely in the literature, and some argue that self-reports are notoriously unreliable [116-119], that self-reported behaviour reflects perceptions or beliefs about people's own behaviour rather than their actual behaviour [119-121], or that people are not even aware of the actual environmental consequences of their individual behaviours [122]. In contrast, it is argued that socially desirable responding is not so much a problem when assessing environmental attitudes and self-reported ecological behaviours [123]. In some studies, observed energy-related behaviours are compared with self-reported measures, and no significant differences between them can be found $[49,124,125]$.

The survey in this study asks for self-reporting of intentions to change actual behaviour. According to the Theory of Planned Behaviour [126,127], human behaviour is guided by three kinds of considerations (behavioural beliefs, normative beliefs, control beliefs), which produce an attitude toward the behaviour, subjective norm and perceived behavioural control. These aspects have been examined in the items about cognitive and affective attributes in the survey. In combination, this leads to the formation of a behavioural intention. According to Ajzen's theory [126] (p. 438), intention is "assumed to be the immediate antecedent of behavior". In this sense, Abrahamse and Steg [128] show that there is a positive relation between attitudes towards energy conservation and actual energy use. There is no doubt that a truly reliable solution to this problem does not yet exist, yet there are various measures which can be, and in the study at hand have been taken in order to reduce the effect of social desirability. In order to further minimise uncertainty, and to examine whether two test items measure the same construct, Cronbach's $\alpha, a$ statistical estimate for internal consistency, was calculated for the items which address the students' intention.

\subsubsection{Young People's Influence on Energy Consumption}

Young people will be affected by challenges connected with climate change and energy-related topics longer and more intensively over their lifetime than any generation before [129]. However, another uncertainty worth being mentioned here is the question as to whether and how much young people can actually influence energy consumption/reduction. Again, there are opposing scientific arguments: On the one hand, young people's scope of action seems limited, since they are not responsible for energy bills in their household (e.g., electricity, heating) or (technical) energy-intensive investments (e.g., heating, car, insulation). However, reducing heating energy and electricity as well as increasing use of public transport, bicycles or car-pooling and choosing products with a smaller environmental impact are actions that lie within their scope of action and, all in all, have a considerable impact [130]. Most of all, the childhood and teenage years seem important for transferring energy related saving habits into adulthood, whereas changing 
habits at a later period in life seems clearly more difficult [131]. Furthermore, different studies indicate that, increasingly with age, children and adolescents can actively influence their parents' and friends' values, attitudes and decisions [81,132,133]. Environmental education programmes for children or teenagers can thus result in spillover effects [102]. However, these have not been considered in the study in order to reduce uncertainty. It should also not be forgotten that adolescence-a period of transition-is the second major window of development for human beings [134]. It is of great importance to enable teenagers to deal with environmental challenges, since change is often driven by young people as they explore the world, put societal behaviours to the test, and develop their own values [135]. Thanks to compulsory school attendance in the industrialised world, there is hardly a target group that is organisationally more accessible than students. Thus, young people qualify as a desirable target group for programmes leading to the increase in energy literacy at cognitive, affective and behavioural levels.

Meter reading was not part of the study as it would have provided insights only into the electricity and heating consumption of a household (both subject to possibly very different winter situations and thus energy consumption patterns in Austria), and would not cover the weighty areas of mobility, nutrition and general consumption in which the students have a potentially high scope of action. Moreover, young people spend a lot of time, and thus use a lot of energy, outside their family households [133].

Taking all things said into consideration, the authors assume that energy education in general, and the Energy Education Initiative presented in this study in specific can lead to considerable impact on individuals' and households' energy consumption/reduction.

\section{Conclusions}

In 2021, a Eurobarometer-survey on climate, environment, and energy shows that European citizens see climate change as the most substantial problem the world is faced with, and thus $78 \%$ consider it a very serious problem (plus $15 \%$ who say it is a serious problem) [136]. All in all, the survey reports on the strong public support for mitigation, adaptation or transformation measures in connection with climate change, environmental protection, and any type of sustainable development. Its results are an encouraging base for further efforts by the European Commission as to becoming "Fit for 55" [137] and reaching ever more serious climate goals. Energy saving and energy efficiency remain high on the agenda, confirming Eurobarometer trends from 2019, where people showed substantial awareness of the energy and climate related problems of our time, and expressed their desire for innovative energy policies, and also said they were personally willing to act as well [136].

In Austria, public awareness and support are similarly high, and it is small wonder that almost countless projects and initiatives take place in ESD, CCE, and also in more specific energy education programmes. This study indicates that the energy education initiative ETSIT contributed to raising students' energy literacy. Directly after and roughly one year after their respective workshop, the vast majority of the participating students reported that their energy literacy increased at cognitive, affective and behavioural level. Despite an unknown degree of social desirability influence on the responses, the results of the online surveys indicate that the Energy Education Initiative ETSIT meets its targets by getting a considerable number of primary and secondary school students closer to becoming energy literate individuals who report their intentions to make wise use of energy in the future and try to save it where possible in their day-to-day lives.

Based on these findings, a number of implications can be formulated:

In the light of the Austrian Energy Efficiency Act, investments in energy education (e.g., through energy suppliers) should, if they result in a measurable or estimable energy saving, be regarded equal to energy audits in private households, and therefore handled as 'offsettable' investments for energy suppliers for the purpose of increasing energy efficiency [19]. Thereby, the results contribute to the debate on the appraisal and the financial perspective of energy education. 
However, the aforementioned uncertainties in the evaluation methodology should not be neglected, but implicitly targeted by additional evidence-based research. Special attention should be paid to defining an equivalent to the quality levels used in the default formula for the monitoring of energy audits. Longitudinal studies with an extensive mixedmethodology approach are needed to find out which specific educational approaches produce positive outcomes and to which degree. A combination of meter data and selfreporting surveys in a pre-test-post-test design could deliver helpful information about the actual impact of energy education on individual and household consumption. However, meter data can only account for household electricity and heating and does not provide insights into the weighty areas of mobility, nutrition and general consumption, in which young people have a potentially high scope of action. In addition, spillover effects as well as rebound effects of energy education require further research as they hold a significant potential to inflate or deflate the actual impact on energy use. Self-reporting surveys could also pay more attention to behavioural patterns ranging from electricity and heating usage over individual mobility to consumption in general and take into account aspects of social desirability as well as demand characteristics effects. The behavioural items in DeWaters et al.'s Energy Literacy Questionnaire [34] could be seen as a starting point but should be extended by further energy efficiency as well as sufficiency measures and adapted to different target groups. Especially in the light of climate scientists' warning about the current state of the Earth's climate on global [138] as well as national/regional level (for Austria, e.g., [139]), it is essential that education activities do not only raise awareness for more sustainable lifestyles, but really lead to action on the ground [140]. Although we could show that even 90 min workshops with only a one-time exposure can have lasting energysaving effects on individuals, it should be considered that multiple exposure measures over a longer period of time might well prove even more successful and sustainable, in terms of measurable energy savings. A comparison of different interventions in their effectiveness would be very interesting. Unfortunately, the current ETSIT initiative workshops are currently on hold due to COVID-19 pandemic restrictions, and it will probably take some time to reinstall them in the future.

Finally, it has to be clear that focusing on quantifying the impacts of educational campaigns on individual and household energy consumption should never lead to any kind of financial or technocratic "fine tuning of education". At the end of the day, it is the individual and collective action as to saving energy and the climate, and thus the transformation of society towards climate-friendly and sustainable development that counts. In light of the post-COP 26 era and the enormous challenges the planet and humanity are confronted with, no goal less important than that should be pursued.

Author Contributions: L.K., M.R., J.S. and S.L.; methodology, M.R., L.K., J.S. and S.L.; formal analysis, L.K., M.R., S.L. and K.H.; investigation, L.K., M.R. and S.L.; data curation: M.R.; writingoriginal draft preparation, L.K., M.R. and S.L.; writing-review and editing, L.K., M.R., K.H. and S.L.; visualization, K.H.; project administration, J.S., M.R., S.L. and L.K.; funding acquisition, J.S. All authors have read and agreed to the published version of the manuscript.

Funding: This research was partly conducted at K1-Centre alpS-Centre for Climate Change Adaptation, Innsbruck, and at the Institute for Geography at the University of Innsbruck. Financial support was provided by the Austrian Research Funding Association (FFG, FFG-Number 843275) within the scope of the COMET programme (Competence Centers for Excellent Technologies), co-funded by TIWAG. This programme was promoted by BMVIT, BMWFW, and the Province of Tyrol. Open-Access Fees for this study were provided by University of Innsbruck, Austria.

Institutional Review Board Statement: Not applicable.

Informed Consent Statement: Informed consent was obtained from all subjects involved in the study.

Data Availability Statement: Data is available from the first author upon request.

Acknowledgments: Special thanks to Karin Oberauer (Austria) for references formatting, and to Lisa Thompson (United Kingdom) for proof-reading. 
Conflicts of Interest: The authors declare no conflict of interest.

\section{References}

1. Meadows, D.H.; Meadows, D.L.; Randers, J.; Behrens, W.W., III. The Limits to Growth. A Report for the Club of Rome's Project on the Predicament of Mankind; Universe Books: New York, NY, USA, 1972.

2. United Nations. Agenda 21. United Nations Conference on Environment and Development Rio de Janerio, Brazil, 3 to 14 June, 1992. Rio de Janeiro. Available online: https:/ / sustainabledevelopment.un.org/content/documents/Agenda21.pdf (accessed on 13 December 2021).

3. Intergovernmental Panel on Climate Change. AR6 Climate Change 2021: Sixth Assessment Report. Available online: https: //www.ipcc.ch/report/ar6/wg1/ (accessed on 13 December 2021).

4. United Nations. UN Climate Change Conference. Available online: https://ukcop26.org/ (accessed on 13 December 2021).

5. Intergovernmental Panel on Climate Change. AR5 Climate Change 2014: Sixth Assessment Report. Available online: https: //www.ipcc.ch/report/ar5/syr/ (accessed on 13 December 2021).

6. United Nations. Framework Convention on Climate Change. Paris Agreement. Available online: https://unfccc.int/processand-meetings/the-paris-agreement/the-paris-agreement (accessed on 13 December 2021).

7. United Nations. Sustainable Development Goals. New York. Available online: https://sustainabledevelopment.un.org/sdgs (accessed on 13 December 2021).

8. United Nations. Educational, Scientific and Cultural Organization. Shaping the Future We Want. UN Decade of Education for Sustainable Development (2005-2014). Final Report. Paris. Available online: Unesdoc.unesco.org/images/0023/002301/230171e. pdf (accessed on 13 December 2021).

9. United Nations. Educational, Scientific and Cultural Organization. UNESCO Roadmap for Implementing the Global Action Programme on Education for Sustainable Development. Paris. Available online: https:/ / sustainabledevelopment.un.org//167 4unescoroadmapp.pdf (accessed on 13 December 2021).

10. United Nations. Educational, Scientific and Cultural Organization. Education for Sustainable Development: A Roadmapp. ESD for 2030. Available online: https:/ / unesdoc.unesco.org/ark:/48223/pf0000374802.locale=en (accessed on 13 December 2021).

11. United Nations. Educational, Scientific and Cultural Organization. Education for Sustainable Development Goals: Learning Objectives. Paris: UNESCO. Available online: https://unesdoc.unesco.org/ark:/48223/pf0000247444 (accessed on 13 December 2021).

12. Keller, L.; Stötter, J.; Oberrauch, A.; Kuthe, A.; Körfgen, A.; Hüfner, K. Changing Climate Change Education: Exploring moderate constructivist and transdisciplinary approaches through the research-education co-operation k.i.d.Z.21. GAIA 2019, 28, 35-43. [CrossRef]

13. Commission of the European Communities. Proposal for a Directive of the from Renewable Sources, Brussels, 23.01.2008, COM (2008) 30 Final. 2008. Available online: https:/ / eur-lex.europa.eu/LexUriServ/LexUriServ.do?uri=COM:2008:0030:FIN:en:PDF (accessed on 8 December 2021).

14. Europäisches Parlament und Rat der Europäischen Union. Amtsblatt der Europäischen Union, 2012. Richtlinie 2012/27/EU des Europäischen Parlaments und des Rates. Available online: https: / eur-lex.europa.eu/LexUriServ /LexUriServ.do?uri=OJ:L:2012: 315:0001:0056:DE:PDF (accessed on 8 December 2021).

15. Barbu, A. EEA. Achieving Energy Efficiency through Behaviour Change: What Does It Take? (EEA Technical Report No 5/2013). Available online: http:/ / www.eea.europa.eu/publications/achieving-energy-efficiency-through-behaviour/download (accessed on 17 December 2021).

16. Zografakis, N.; Menegaki, A.; Tsagarakis, K.P.P. Effective education for energy efficiency. Energy Policy 2008, 36, 3226-3232. [CrossRef]

17. European Commission. Delivering the European Green Deal. Available online: https:/ /ec.europa.eu/info/strategy/priorities-20 19-2024/european-green-deal/delivering-european-green-deal_en (accessed on 12 December 2021).

18. Eur-Lex. Proposal for a Directive of the European Parliament and of the Council on Energy Efficiency (Recast). Available online: https:/ / eur-lex.europa.eu/legal-content/EN/TXT/?uri=CELEX:52021PC0558 (accessed on 13 December 2021).

19. Rechtsinformationssystem des Bundes. Bundesgesetz über Die Steigerung der Energieeffizienz bei Unternehmen und dem Bund (Bundes-Energieeffizienzgesetz-EEffG) StF: BGBl. I Nr. 72/2014. Available online: https:/ /www.ris.bka.gv.at/GeltendeFassung. wxe? Abfrage=Bundesnormen\&Gesetzesnummer=20008914 (accessed on 13 December 2021).

20. Institut für Energie und Umweltforschung Heidelberg GmbH. Evaluation der Stationären Energieberatung der Verbraucherzentralen, des Deutschen Hausfrauenbundes Niedersachsen und des Verbraucherservice Bayern. Endbericht im Auftrag des Verbraucherzentrale Bundesverbandes e.V.; Institut für Energie und Umweltforschung Heidelberg GmbH: Heidelberg, Germany, 2005. Available online: https:/ / docplayer.org/41853856-Evaluation-der-stationaeren-energieberatung-der-verbraucherzentralen-des-deutschenhausfrauenbundes-niedersachsen-und-des-verbraucherservice-bayern.html (accessed on 13 December 2021).

21. Opinion Dynamics Corporation. Indirect Impact Evaluation of the Statewide Energy Efficiency Education and Training Program. 2008. Available online: http://www.calmac.org/publications/06-08_Statewide_Education_and_Training_Impact_Eval_Vol_I_ FINAL.pdf (accessed on 17 December 2021).

22. Bello, A.A.; Agabo, T.; Adedoyinc, F. The anthropogenic consequences of energy consumption in Sub-Saharan Africa: Is there a role for education. Environ. Chall. 2021, 5, 100234. [CrossRef] 
23. Sharygin, E. The Carbon Cost of an Educated Future: A Consumer Lifestyle Approach. Available online: https://ideas.repec.org/ p/vid/wpaper/1304.html (accessed on 13 December 2021).

24. Ackerman, F.; Heinzerling, L. Pricing the Priceless: Cost-Benefit Analysis of Environmental Protection. Univ. PA Law Rev. 2002, 150, 1553-1584. [CrossRef]

25. Winkler, H.; Spalding-Fecher, R.; Tyani, L.; Matibe, K. Cost-benefit analysis of energy efficiency in urban low-cost housing. Dev. S. Afr. 2002, 19, 593-614. [CrossRef]

26. Friedman, C.; Becker, N.; Erell, E. Energy retrofit of residential building envelopes in Israel: A cost-benefit analysis. Energy 2014, 77, 183-193. [CrossRef]

27. Wang, X.; Lu, M.; Mao, W.; Ouyang, J.; Zhou, B.; Yang, Y. Improving benefit-cost analysis to overcome financing difficulties in promoting energy-efficient renovation of existing residential buildings in China. Appl. Energy 2015, 141, 119-130. [CrossRef]

28. Rosenow, J.; Bayer, E. Costs and benefits of Energy Efficiency Obligations: A review of European programmes. Energy Policy 2017, 107, 53-62. [CrossRef]

29. Yushchenko, A.; Patel, K. Cost-effectiveness of energy efficiency programs: How to better understand and improve from multiple stakeholder perspectives? Energy Policy 2017, 108, 538-550. [CrossRef]

30. Mansuelo, R.; Domingos, A.; Oscar, F.; Pereira, R. Comparative cost-benefit analysis of the energy efficiency measures and photovoltaic generation in houses of social interest in Brazil. Energy Build. 2021, 243, 111013.

31. Clinch, J.P.P.; Healy, J.D. Cost-benefit analysis of domestic energy efficiency. Energy Policy 2001, 29, 113-124. [CrossRef]

32. Freed, F.; Felder, A. Non-energy benefits: Workhorse or unicorn of energy efficiency programs? Electr. J. 2017, 30, 43-46. [CrossRef]

33. Wisconsin Center for Environmental Education; Wisconsin K-12 Energy Education Program; College of Natural Resources; University of Wisconsin-Steven Point 2016. Wisconsin K-12 Energy Education Program (KEEP). 20 Years of Empowering Energy Education in Wisconsin 1995-2015. Preparing Communities to Make Informed Energy Choices Now and for a Sustainable Future. Available online: https: / / issuu.com/dmartinswcee/docs/keep_20_year_report (accessed on 14 December 2021).

34. De Waters, J.; Qaqish, B.; Graham, M.; Powers, S. Designing an Energy Literacy Questionnaire for Middle and High School Youth. J. Environ. Educ. 2013, 44, 56-78. [CrossRef]

35. Lefkeli, S.; Tsantopoulos, G.; Manolas, E. Climate Change and Renewable Energy: Opinions and Emotions of Elementary School Pupils in the Prefecture of Evros. In Handbook of Climate Change Communication; Leal Filho, W., Manolas, E., Azul, A.M., Azeiteiro, U.M., McGhie, H., Eds.; Springer: Hamburg, Germany, 2018; pp. 223-236.

36. Barrow, L.H.; Morrisey, J.T. Energy literacy of ninth-grade students: A comparison between Maine and New Brunswick. J. Environ. Educ. 1989, 20, 22-25. [CrossRef]

37. Crater, H.L.; Mears, D.E. Evaluating attitudes toward, and knowledge of, energy problems in the eighth grade. Sch. Sci. Math. 1981, 81, 121-123. [CrossRef]

38. Gambro, J.S.; Switzky, H.N. Variables associated with American high school students' knowledge of environmental issues related to energy and pollution. J. Environ. Educ. 1999, 30, 15-22. [CrossRef]

39. Kuhn, D.J. Study of the attitudes of secondary school students toward energy-related issues. Sci. Educ. 1979, 63, 609-620. [CrossRef]

40. Lawrenz, F. Student knowledge of energy issues. Sch. Sci. Math. 1983, 83, 587-595. [CrossRef]

41. Lawrenz, F.; Dantchik, A. Attitudes toward energy among students in grades 4, 7 and high school. Sch. Sci. Math. 1985, 85, 189-202. [CrossRef]

42. Finegold, M.; Trumper, R. Categorizing pupils' explanatory frameworks in energy as a means to the development of a teaching approach. Res. Sci. Educ. 1989, 19, 97-110. [CrossRef]

43. Singh, C.; Rosengrant, D. Multiple-choice test of energy and momentum concepts. Am. J. Phys. 2003, 71, 607-617. [CrossRef]

44. Swackhamer, G.; Hestenes, D. An Energy Concept Inventory; Glenbrook North High School and Arizona State University: Phoenix, AZ, USA, 2003.

45. National Energy Education Development Project (NEED). Secondary Energy Poll. Available online: http://www.need.org/ needpdf/SecondaryPoll.pdf (accessed on 8 March 2021).

46. Nordine, J. Supporting Middle School Students' Development of an Accurate and Applicable Energy Concept. Ph.D. Thesis, University of Michigan, Ann Arbor, MI, USA, 2007.

47. Rendl, N.K. The Infusion and Evaluation of KEEP (K-12 Energy Education Program). Master's Thesis, University of Wisconsin, Madison, WI, USA, Stevens Point, WI, USA, 2000.

48. Adensam, H.; Bogner, T.; Geissler, S.; Groß, M.; Hofmann, M.; Krawinkler, R.; Kulterer, K.; Ploiner, C.; Renner, S.; Simader, G.; et al. Methoden zur Richtlinienkonformen Bewertung der Zielerreichung Gemäß Energieeffizienz- und EnergiedienstleistungsrichtLinie 2006/32/EG. Bottom-up Methoden. Available online: https://www.monitoringstelle.at/fileadmin/i_m_at/pdf/ Methodendokument_RK_AT_Okt13.pdf (accessed on 13 December 2021).

49. Abrahamse, W.; Steg, L.; Vlek, C.; Rothengatter, T. A review of intervention studies aimed at household energy conservation. J. Environ. Psychol. 2005, 25, 273-291. [CrossRef]

50. Energie Tirol. Energie Tirol-Die Unabhängige Energieberatung. Available online: https://www.energie-tirol.at/energieakademie/energie-akademie-fuer-kinder/ (accessed on 15 December 2021).

51. International Association of Universities. The Impact of COVID-19 on Higher Education around the World. Available online: https://www.iau-aiu.net/IMG/pdf/iau_covid19_and_he_survey_report_final_may_2020.pdf (accessed on 17 December 2021). 
52. Frick, M.; Neu, L.; Liebhaber, N.; Sperner-Unterweger, B.; Stötter, J.; Keller, L.; Hüfner, K. Why Do We Harm the Environment or Our Personal Health Despite Better Knowledge? The Knowledge Action Gap in Healthy and Climate-Friendly Behavior. Sustainability 2021, 13, 13361. [CrossRef]

53. Bodner, G.M. Constructivism. A theory of knowledge. J. Chem. Educ. 1986, 63, 873. [CrossRef]

54. Duffy, T.M.; Jonassen, D.H. (Eds.) Constructivism and the Technology of Instruction. A Conversation; Routledge: Hillsdale, MI, USA, 1992.

55. Von Glasersfeld, E. Radical Constructivism: A Way of Knowing and Learning; Studies in Mathematics Education Series: London, UK; Washington, DC, USA, 1995.

56. Fosnot, C.T. (Ed.) Constructivism. Theory, Perspectives, and Practice; Teachers College Press: New York, NY, USA, 2005.

57. Cardellini, L. The Foundations of Radical Constructivism. An Interview with Ernst von Glasersfeld. Found. Chem. 2006, 8, 177-187. [CrossRef]

58. Bednar, A.K.; Cunningham, D.; Duffy, T.M.; Perry, D.J. Theory into Practice: How do we link? In Constructivism and the Technology of Instruction. A Conversation; Duffy, T.M., Jonassen, D.H., Eds.; Routledge: New York, NY, USA; Abingdon, VA, USA, 1992; pp. 17-34.

59. Carey, S. Knowledge acquisition: Enrichment or conceptual change? In The Epigenesis of Mind: Essays on Biology and Cognition; Jean Piaget Symposia Series; Carey, S., Gelman, R., Eds.; Psychology Press: New York, NY, USA; Hove, UK, 1991 ; pp. $257-291$.

60. Cognition and Technology Group at Vanderbilt University. Some thoughts about constructivism and instructional design. In Constructivism and the Technology of Instruction. A Conversation; Duffy, T.M., Jonassen, D.H., Eds.; Routledge: New York, NY, USA; Abingdon, VA, USA, 1992; pp. 115-120.

61. Duit, R.; Treagust, D.F. Conceptual change: A powerful framework for improving science teaching and learning. Int. J. Sci. Educ. 2003, 25, 671-688. [CrossRef]

62. Ernest, P.P. The one and the many. In Constructivism in Education; Steffe, L., Gale, J., Eds.; Erlbaum: Hillsdale, MI, USA, 1995; pp. 459-486.

63. Posch, A.; Stauffacher, M.; Walter, A.I.; Lang, D.J.; Wiek, A.; Scholz, R.W. Learning to research environmental problems from a functional socio cultural constructivism perspective. Int. J. Sustain. High. Educ. 2006, 7, 252-275. [CrossRef]

64. Posner, G.J.; Strike, K.A.; Hewson, P.P.W.; Gertzog, W.A. Accommodation of a scientific conception. Toward a theory of conceptual change. Sci. Educ. 1982, 66, 211-227. [CrossRef]

65. Garrison, D.R. Thinking Collaboratively. Learning in a Community of Inquiry; Routledge: New York, NY, USA; Abingdon, VA, USA, 2016.

66. Leat, D. Enquiry and Project Based Learning. Student, School and Society; Routledge: New York, NY, USA; Abingdon, VA, USA, 2015.

67. Littleton, K.; Scanlon, E.; Sharples, M. Orchestrating Inquiry Learning; Routledge: New York, NY, USA; Abingdon, VA, USA, 2012.

68. Maßß, K.; Artigue, M. Implementation of inquiry-based learning in day-to-day teaching: A synthesis. ZDM 2013, 45, 779-795. [CrossRef]

69. Ovens, P.; Wells, F.; Wallis, P.; Hawkins, C. Developing Inquiry for Learning. Reflecting Collaborative Ways to Learn How to Learn in Higher Education; Routledge: New York, NY, USA; Abingdon, VA, USA, 2011.

70. Perkins, D.N. Technology meets constructivism: Do they make a marriage? In Constructivism and the Technology of Instruction. A Conversation; Duffy, T.M., Jonassen, D.H., Eds.; Routledge: New York, NY, USA; Abingdon, VA, USA, 1992 ; pp. 54-56.

71. Solomon, J. The Rise and Fall of Constructivism. Stud. Sci. Educ. 1994, 23, 1-19. [CrossRef]

72. White, B.Y.; Frederiksen, J.R. Inquiry, modeling, and metacognition: Making science accessible to all students. Cogn. Instr. 1998, 16, 18-31. [CrossRef]

73. Döring, N.; Bortz, J. Forschungsmethoden und Evaluation in den Sozial- und Humanwissenschaften; Springer: Heidelberg, Germany, 2015.

74. Kuckartz, U.; Rädiker, S. (Eds.) Erziehungswissenschaftliche Evaluationspraxis; Beltz Juventa Verlag: Weinheim, Germany; Basel, Switzerland, 2012.

75. Müller-Kohlenberg, H. Empfehlungen zur Anwendung der Standards für Evaluation im Handlungsfeld der Selbstevaluation; DeGeval Geschäftsstelle: Alfter, Germany, 2004.

76. Stefer, C. Der Online-Fragebogen in der Evaluation. Potenziale und Grenzen des Instruments. In Erziehungswissenschaftliche Evaluationspraxis; Kuckartz, U., Rädiker, S., Eds.; Beltz Juventa Verlag: Weinheim, Germany; Basel, Switzerland, 2012 ; pp. 156-168.

77. Garland, R. The Mid-Point on a Rating Scale: Is it Desirable? Mark. Bull. 1991, 2, 66-70.

78. Morgan, G.B.; Johnson, R.L. Survey Scales: A Guide to Development, Analysis, and Reporting. Guilford Publications; Guilford Press: New York, NY, USA, 2016.

79. Riede, M.; Kuthe, A.; Keller, L.; Greissing, A. Development, application, and impact assessment of a moderate-constructivist intervention to prepare teenagers for challenges of climate change and energy transition. Umweltpsychologie 2016, 38, 39-61.

80. Energie-Control Austria. Energieeffizienz. Profitieren. Überall, Wo Energie Effizient Genutzt Wird. Available online: http:/ / www.e-control.at/portal/page/portal/medienbibliothek/oeko-energie/dokumente/pdfs/e-control-energie-effizienzfolder-2012.pdf (accessed on 30 September 2021).

81. Parth, S.; Schickl, M.; Keller, L.; Stoetter, J. Quality Child-Parent Relationships and Their Impact on Intergenerational Learning and Multiplier Effects in Climate Change Education. Are We Bridging the Knowledge-Action Gap? Sustainability 2020, 12, 7030. [CrossRef] 
82. Ramsey, C.E.; Rickson, R.E. Environmental knowledge and attitudes. J. Environ. Educ. 1976, 8, 10-18. [CrossRef]

83. Hungerford, H.R.; Volk, T.L. Changing learner behavior through environmental education. J. Environ. Educ. 1990, $21,8-21$. [CrossRef]

84. Newhouse, N. Implications of attitude and behavior research for environmental conservation. J. Environ. Educ. 1990, 22, 26-32. [CrossRef]

85. Stern, P.P.C. What psychology knows about energy conservation. Am. Psychol. 1992, 47, 1224. [CrossRef]

86. Stern, P.P.C. Toward a coherent theory of environmentally significant behavior. J. Soc. Issues 2000, 56, 407-424. [CrossRef]

87. Hines, J.M.; Hungerford, H.; Tomera, A. Analysis and synthesis of research on responsible environmental behavior. J. Environ. Educ. 1987, 19, 1-8. [CrossRef]

88. Owens, S.; Driffill, L. How to change attitudes and behaviors in the context of energy. Energy Policy 2008, 36, 4412-4418. [CrossRef]

89. Keller, L. "Sustainable Development?-Let Us Change Concepts!" Theoretical and Practical Contributions to the Transformation of Society, Science, Knowledge, and Education from a Geographer's Perspective. Mater's Thesis, University of Innsbruck, Innsbruck, Austria, 2 July 2018.

90. Costanzo, M.; Archer, D.; Aronson, E.; Pettigrew, T. Energy conservation behavior: The difficult path from information to action. Am. Psychol. 1986, 41, 521. [CrossRef]

91. Dunlop, D.L. An energy-environment simulator. J. Environ. Educ. 1979, 10, 43-48. [CrossRef]

92. Kurisu, K. What Are Pro-Environmental Behaviors (PEBs)? In Pro-Environmental Behaviors; Kurisu, K., Ed.; Springer: Tokyo, Japan, 2015; pp. 1-26.

93. Murphy, T.P.P. The Minnesota Report Card on Environmental Literacy: A Benchmark Survey of Adult Environmental Knowledge, Attitudes and Behavior; Minnesota Office of Environmental Assistance, Hamline University, Center for Global Environmental Education: St. Paul, MN, USA, 2002.

94. Sawitria, D.R.; Hadiyantob, H.; Hadic, S.P.P. Pro-Environmental Behavior from a Social Cognitive Theory Perspective. Procedia Environ. Sci. 2015, 23, 27-33. [CrossRef]

95. De Waters, J.E.; Powers, S.E. Energy literacy of secondary students in New York State (USA): A measure of knowledge, affect, and behavior. Energy Policy 2011, 39, 1699-1710. [CrossRef]

96. Jones, R.V.; Lomas, K.J. Determinants of high electrical energy demand in UK homes: Socio-economic and dwelling characteristics. Energy Build. 2015, 101, 24-34. [CrossRef]

97. Otto, S. The development of children's environmental attitude and behavior. Glob. Environ. 2019, 58, 101947. [CrossRef]

98. Grosche, P.P.; Vance, C. Willingness to Pay for Energy Conservation and Free-Ridership on Subsidization: Evidence from Germany. Energy J. 2009, 30, 135-153. [CrossRef]

99. Greening, L.A.; Greene, D.L.; Difiglio, C. Energy efficiency and consumption—The rebound effect-A survey. Energy Policy 2000, 28, 389-401. [CrossRef]

100. Vivanco, D.F.; Kemp, R.; van der Voeta, E. How to deal with the rebound effect? A policy-oriented approach. Energy Policy 2016, 94, 114-125. [CrossRef]

101. Hiramatsu, A.; Kurisu, K.; Nakamura, H.; Teraki, S.; Hanaki, K. Spillover Effect on Families Derived from Environmental Education for Children. LCE 2014, 5, 40-50. [CrossRef]

102. Koesler, S.; Swales, K.; Turner, K. International spillover and rebound effects from increased energy efficiency in Germany. Energy Policy 2016, 54, 444-452. [CrossRef]

103. Penz, E.; Hartl, B.; Hofmann, E. Explaining consumer choice of low carbon footprint goods using the behavioral spillover effect in German-speaking countries. J. Clean. Prod. 2019, 214, 429-439. [CrossRef]

104. Arimura, T.H.; Iwata, K.; Katayama, H.; Sakudo, M. Seemingly Unrelated Interventions: Environmental Management Systems in the Workplace and Energy Saving Practices at Home. Environ. Resource Econ. 2021, 80, 761-794. [CrossRef]

105. Bundesministerium für Klimaschutz, Umwelt, Energie, Mobilität, Innovation und Technologie, Was Kostet Uns die Klimakrise? Available online: https:/ /infothek.bmk.gv.at/studie-folgekosten-klimakrise-klimafonds / (accessed on 15 December 2021).

106. Allcott, H.; Mullainathan, S. Behaviour and Energy Policy. Science 2010, 32, 1204-1205. [CrossRef]

107. Radhakrishna, R.B. Tips for Developing and Testing Questionnaires/Instruments. JOE 2007, 45, 1 TOT2.

108. Rubin, M.; Badea, C. The central tendency of a social group can affect ratings of its intragroup variability in the absence of social identity concerns. J. Exp. Soc. Psychol. 2010, 46, 410-415. [CrossRef]

109. Headley, M.G.; Plano Clark, V.L. Multilevel Mixed Methods Research Designs: Advancing a Refined Definition. J. Mix. Methods Res. 2020, 14, 145-163. [CrossRef]

110. Kuckartz, U.; de Haan, G. Umweltbewußtsein. Denken und Handeln in Umweltkrisen; Westdeutscher Verlag: Wiesbaden, Germany, 1996

111. De Haan, G.; Kuckartz, U. Umweltbildung und Umweltbewußtsein. Forschungsperspektiven im Kontext Nachhaltiger Entwicklung (Schriftenreihe Öekologie und Erziehungswissenschaft der Arbeitsgruppe Umweltbildung der Deutschen Gesellschaft für Erziehungswissenschaft; Leske \& Budrich: Opladen, Germany, 1998.

112. Mandl, H.; Gerstenmaier, J. Die Kluft Zwischen Wissen und Handeln. Empirische und Theoretische Lösungsansätze; Hogrefe Verlag für Psychologie: Göttingen, Germany; Bern, Switzerland; Toronto, ON, Canada; Seattle, WA, USA, 2000.

113. De Haan, G. The development of ESD-related competencies in supportive institutional frameworks. Int. Rev. Educ. 2010, 56, 315-328. [CrossRef] 
114. O'Brien, K.L. Global environmental change III: Closing the gap between knowledge and action. Prog. Hum. Geogr. 2012, 37, 587-596. [CrossRef]

115. Frederiks, K.S.; Stenner, K.; Hobman, E.V. Household energy use: Applying behavioural economics to understand consumer decision-making and behaviour. Renew. Sustain. Energy Rev. 2015, 41, 1385-1394. [CrossRef]

116. Corral-Verdugo, V. Dual 'realities' of conservation behavior: Self-reports vs. observations of reuse and recycling behavior. J. Environ. Psychol. 1997, 17, 135-145. [CrossRef]

117. Porter, B.E.; Leeming, F.C.; Dwyer, W.O. Solid waste recovery: A review of behavioral programs to increase recycling. Environ. Behav. 1995, 27, 122-152. [CrossRef]

118. Rathje, W.L.; Murphy, C. Rubbish! The Archaeology of Garbage; Harper Perennial: New York, NY, USA, 1994.

119. Chao, Y.-L.; Lam, S.-P.P. Measuring Responsible Environmental Behavior: Self-Reported and Other-Reported Measures and Their Differences in Testing a Behavioral Model. Environ. Behav. 2010, 43, 53-71. [CrossRef]

120. Olson, M.E. Consumers' attitudes toward energy conservation. J. Soc. Issues 1981, 37, 108-131. [CrossRef]

121. Gatersleben, B.; Steg, L.; Vlek, C. Measurement and Determinants of Environmentally Significant Consumer Behavior. Environ. Behav. 2002, 34, 335-362. [CrossRef]

122. Baird, J.C.; Brier, J.M. Perceptual awareness of energy requirements of familiar objects. J. Appl. Psychol. 1981, 66, 90-96. [CrossRef]

123. Milfont, T.L. The effects of social desirability on self-reported environmental attitudes and ecological behaviour. Environmentalist 2009, 29, 263-269. [CrossRef]

124. Warriner, G.K.; McDougall, G.H.C.; Claxton, J.D. Any data or none at all? Living with inaccuracies in self-reports of residential energy consumption. Environ. Behav. 1984, 16, 503-526. [CrossRef]

125. Kaiser, F.G.; Wölfing, S.; Fuhrer, U. Environmental attitude and ecological behaviour. J. Environ. Psychol. 1999, 19, 1-19. [CrossRef]

126. Ajzen, I. The Theory of Planned Behavior. Organ. Behav. Hum. Decis. Processes 1991, 50, 179-211. [CrossRef]

127. Ajzen, I. The theory of planned behaviour: Reactions and reflections. Psychol Health 2011, 26, 1113-1127. [CrossRef] [PubMed]

128. Abrahamse, W.; Steg, L. Factors Related to Household Energy Use and Intention to Reduce It: The Role of Psychological and Socio-Demographic Variables. Hum. Ecol. Rev. 2011, 18, 30-40.

129. Schrot, O.G.; Peduzzi, D.; Ludwig, D.; Riede, M.; Keller, L. Is it possible to build adolescents' cognitive adaptive capacity through climate change education? Insights into a two-year long educational programme in North Tyrol (Austria) and South Tyrol (Italy). Clim. Risk Manag. 2021, 32, 100319. [CrossRef]

130. Aguirre-Bielschowsky, I.; Lawson, R.; Stephenson, J.; Todd, S. Kids and Kilowatts: Socialisation, energy efficiency, and electricity consumption in New Zealand. Energy Res. Soc. Sci. 2018, 44, 178-186. [CrossRef]

131. Evans, G.W.; Otto, S.; Kaiser, F.G. Childhood origins of young adult environmental behavior. Psychol. Sci. 2018, $29,679-687$. [CrossRef]

132. Ballantyne, R.; Connell, S.; Fien, J. Students as Catalysts of Environmental Change: A framework for researching intergenerational influence through environmental education. Environ. Educ. Res. 1998, 4, 285-298. [CrossRef]

133. Toth, N.; Little, L.; Read, J.C.; Fitton, D.; Horton, M. Understanding teen attitudes towards energy consumption. J. Environ. Psychol. 2013, 34, 36-44. [CrossRef]

134. Dahl, R.E.; Allen, N.B.; Wilbrecht, L.; Suleiman, A.B. Importance of investing in adolescence from a developmental science perspective. Nature 2018, 554, 441-450. [CrossRef]

135. Sercombe, H. Risk, adaptation and the functional teenage brain. Brain Cogn. 2014, 89, 61-69. [CrossRef]

136. European Commission. Eurobarometer on Climate Change. Available online: https://europa.eu/eurobarometer/surveys/ detail/2273 (accessed on 12 December 2021).

137. Eur-Lex. Communication from the Commission to the European Parliament, the Council, the European Economic and Social Committee and the Committee of the Regions 'Fit for 55': Delivering the EU's 2030 Climate Target on the Way to Climate Neutrality. COM/2021/550 Final. Available online: https:/ / eur-lex.europa.eu/legal-content/EN/TXT/?uri=CELEX:52021DC0550 (accessed on 13 December 2021).

138. Rockström, J.; Gupta, J.; Lenton, T.M.; Qin, D.; Lade, S.J.; Abrams, J.F.; Jacobson, L.; Rocha, J.C.; Zimm, C.; Bai, X.; et al. Identifying a safe and just corridor for people and the planet. Earth's Future 2021, 9, e2020EF001866. [CrossRef]

139. Kromp-Kolb, H.; Nakicenovic, N.; Steininger, K.; Gobiet, A.; Formayer, H.; Köppl, A.; Prettenthaler, F.; Stötter, J.; Schneider, J. (Eds.) Österreichischer Sachstandsbericht Klimawandel Austrian Panel on Climate Change (APCC). Austrian Assessment Report 2014 (AAR14); Verlag der Österreichischen Akademie der Wissenschaften: Vienna, Austria, 2014.

140. Kubisch, S.; Parth, S.; Deisenrieder, V.; Oberauer, K.; Stötter, J.; Keller, L. From Transdisciplinary Research to Transdisciplinary Education. The Role of Schools in Contributing to Community Well-Being and Sustainable Development. Sustainability 2021, 13, 306. [CrossRef] 